\title{
ゴールデンホーン橋の構造特性 \\ STRUCTURE CHARACTERISTIC OF \\ THE GOLDEN HORN BRIDGE
}

\author{
成 瀬 輝 男* \\ By T'eruo NARUSE
}

\section{1. まえがき}

ひとつの路面を支えるのに 2 本のI 断面主桁を用いて いる意味では，二主桁橋は本質的な新しさを持っていな い。類似形式のものは日本では上路橋よりもむしろ下路 形式の道路・鉄道橋に数多くの実績がある。最近の二主 桁橋にしいて新しさを見出すとすれば，従来は路面高を 制約された下路橋に限ってやむをえず用いていたのに対 し, 最近は広幅員・大支間の上路橋に積極的に用い始め ている点であろう。しかしながら適用対象の大型化につ れて検討課題もまた質的に変わってくることは自明であ る。以下本稿においては最近トルコ国において完成した ゴールデンホーン橋（以下 “本橋”）の計画・施工段階
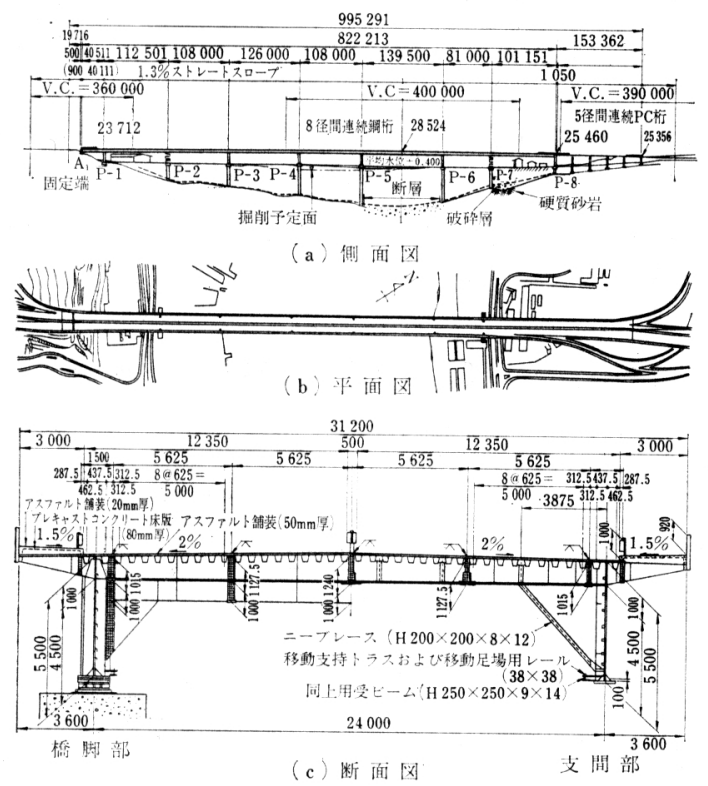

図一1 ゴールデンホーン橋一般図

\footnotetext{
* 正会員 石川島播磨重工業（株）鉄構基本設計部次長
}

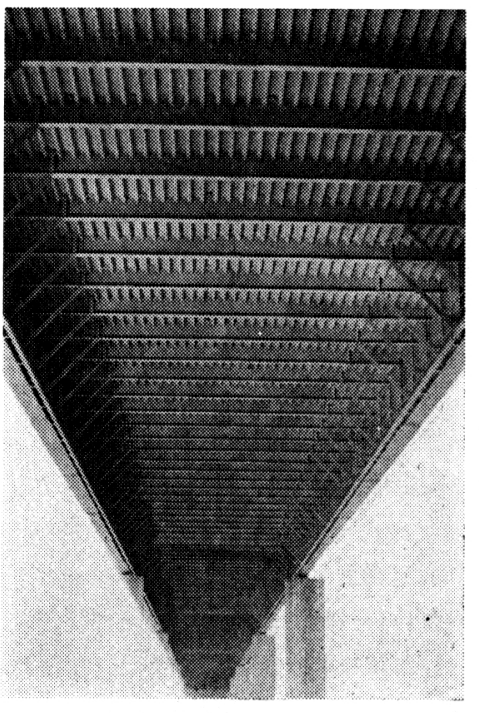

写真-1 完成橋梁下面

で研究した諸事項, 完成後行われた載荷実験について報 告する。

本橋は欧亜を結ぶボスポラス 計画の一環として 1971 年トルコ政府より 2 か年半の工期で発注されたものであ る。トルコ政府より指示された設計条件は, 米国 AAS$\mathrm{HO}$ 示方書 (1969 年版) に準拠することを原則としてい たが，設計荷重はその $10 \%$ 増をとることのほか，たわ み制限や疲労強度に関していくつかの特記仕様が与えら れていた。図一1 に一般図を，写真一1 に完成後の鋼橋 下面を示す。使用鋼材は主桁下縁部が SM 58, 主桁上縁 と鋼床版は SM 53 ないし SM 50 Y である。本橋の鋼 重は $7000 \mathrm{t}$, 歩道を含む単位橋面積当り鋼 重（主 構造 および支承) は $268 \mathrm{~kg} / \mathrm{m}^{2}$ である。

\section{2. 下フランジの座屈安定}

一般にプレートガーダーの圧縮フランジの座屈は次の 
いずれかあるいはこれらを連成した形で発生する。

（1）フランジを構成する単板の局部座屈

(2) フランジ全体の鉛直方向の座屈

(3) " のねじり座屈

（4）"の水平方向の座屈

二主栴橋についても基本的には同じであるが，一般のプ レートガーダーと多少趣を異にするのは, 腹板とフラン ジの断面積比率である。多主桁の場合と比べると, 二主 桁橋は桁数が 2 本のみであるからフランジが大型化する のは当然である。腹板内の作用力として増大するのはせ ん断力のみである。しかし多主桁の場合腹板のせん断力 に対する耐力は応力的にみて大幅な余裕を残しているか ら，主析数を 2 本にしても腹板厚が著しく増大寸ること はない。本橋についていえば, 腹板厚は 10〜14 mm の 範囲にとどまり，また腹板/フランジの総断面積比が 2 を 越える箇所は皆無で場所によっては 1 に近い。フランジ の座屈に対する腹板の拘束力も当然隇少するから，二主 析橋の大型の下フランジの座屈安定問題はむしろ圧縮力 をうける柱に準じて扱うべきである。図一1に示すよう に本橋の下フランジを柱状の中空断面としたのもこの観 点によるものである。腹板とフランジ板の隅角部に斜板 (以下隅板,フランジの一部として応力を分担する) を 設け上記 (1)〜 (3) に対処することにより，本橋のフラ ンジの座屈安定照査は (4), 特にもっともきびしい状態 としてカンチレバー架設中の下フランジ全体の横座屈の 問題に集中した。まず下フランジを“ニーブレースで弾 性的に支持されかつ軸方向に断面積・軸力とも逐次変化 する柱”として解析的な検討を加えた。ニーブレース連 結点での水平方向の弾性支持係数法次の二つの因子の影 響を重㸚わせる形で考慮した。

（1）横リブ, ニーブレースおよび主桁腹板の垂直補
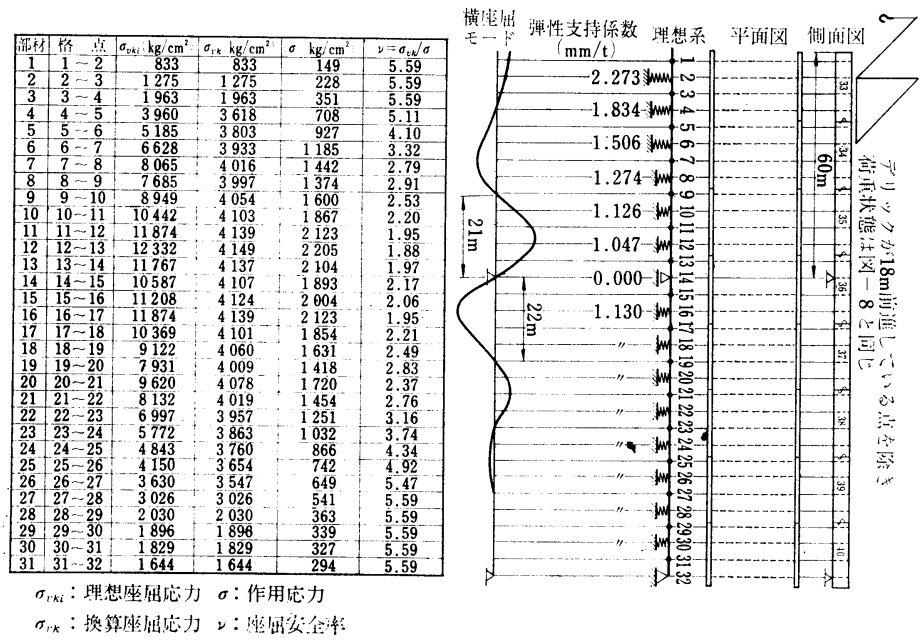

図一2 主桁下フランジのカンチレバー架設中の横座屈照查
剛材で構成される門型ラーメンの脚端の横変位。この場 合は 2 つ下フランジがともに内側あるいはともに外側 へ，つまり相対する方向に変位する場合を想定したもの で，鋼床版横 リブ断面が一定なので弾性支持俰数も一 定。

（2）橋体全断面の曲げねじり変形に伴う下フランジ の横変位。この場合は二つの下フランジが同方向に変位 する場合を想定したもので，ねじり回転量の橋軸方向変 化に伴い弾性支持係数も軸方向に変化する。

計算結果の要約を図一2に示す。ここには記載を省略 するが，弾性支持係数の見込み誤差に対する下フランジ の座屈個有值および座屈モードの敏感性をも検討し, 結 果として弾性支持係数をかなり低下させてもその影響は 僅少であることを確認した(文献 2))。以上は下フランジ が平面的に直線であるという前提で解析したものである が，さらに下フランジが初期不整を有する場合について も検討を加えた。図一2 に示寸座屈モードに相似した初 期曲がりを柱に与えて計算したもので, 無応力状態にお ける初期曲がり量として座屈モードの半波長の $1 / 1000$ を与え, 軸力を 0 から $400 \mathrm{t}$ ごとに増加し，これらの軸 力によって逐次付加される曲がり量を初期曲がり量に追 加しながら, 非線形的に増大する横曲げ応力を追跡した ものである。結論として設計軸力下に扔ける作用応力は 横曲げ影響を加えても材料 (SM 58)の比例限以下である こと, 少なくとも設計軸力下に拉いて下フランジの不安 定現象はありえないこと, 下フランジの弾性曲がりによ って生じるニーブレースの軸力は $\pm 38.3 \mathrm{t}$ でありニー ブレースの設計耐力以下であること，などを確認した。 このような解析的な検討と平行して，1/8 の大型模型に よって, カンチレバー状態にある橋体の耐力確認害験を 行い, 作用応力を弾性限いっぱいまで上げても下フラン ジに不安定現象はないこと, そのさいの ニーブレース応力は $\pm 200 \mathrm{~kg} / \mathrm{cm}^{2}$ 程度 であることなどを確認した（文献 3))。

\section{3. 残留応力の照査}

さきに述べた圧縮フランジの初期曲が りのような幾何学的な不完全さと別に, 圧縮材のもつ不完全要素のひとつとして 残留応力の問題がある。本橋は通常の I 桁に比し,

（1）下フランジが厚さ・幅とも大きい。

（2）フランジと腹板の隅角部に隅板を有 する。

（3）通常のI 断面では圧縮フランジと腹 板間の溶接線は 2 本であるが, 本橋 の場合隅板の存在により溶接線は 6 


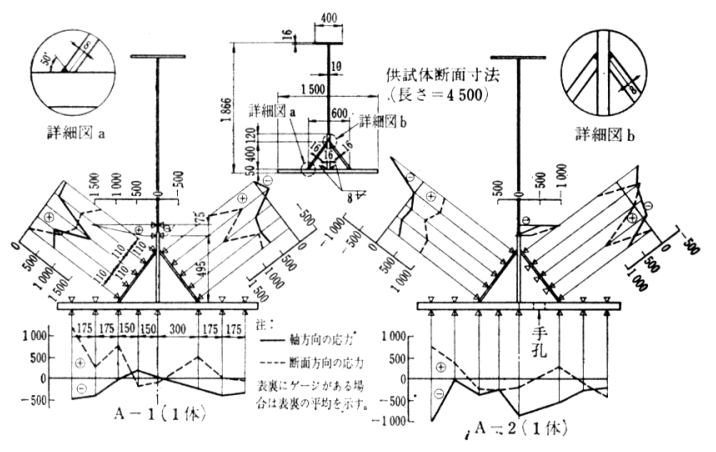

図一3 供試体 A-1 および A-2 の残留応力の分布

(単位: 応力 $\mathrm{kg} / \mathrm{cm}^{2}$, 長さ $\mathrm{mm}$ )

本でしかも2段階に溶接が行われる。 などの諸点で相違している。本橋の架設工法とも関連し て，下フランジ周辺の残留応力の大きさと分布形状を巨 視的に把握することは設計者として関心があったので， 図一3 に示寸原寸大供試体 2 体によって残留応力の測定 を行った。供試体の材質注実橋の桁下縁と同じく SM 58 で，実橋部材の製造工場で実橋部材と同じ条件で製 作した。すなわち上下 2 段の腹板の縦継手は自動溶接に より，また腹板とフランジおよび隅板上下縁の継手は半 自動溶接により行った。供試体のフランジには突合せ溶 接がないが，実橋の部材においてもフランジの突合せ溶 接は皆無であるから, この点も同条件である。残留応力 の計測はセクショニング法により行われた。閉断面につ いては内面のゲージ貼付が困難なので，A-1 については 外面のみとしたが，A-2 についてはフランジ板に手孔 を設け片側の隅板内面にもゲージを貼付した。ゲージに は (株) 昭和測器製 自己温度補償型ストレイングージ SFT-5 を使用した。図一3 は $50 \times 50 \mathrm{~mm}$ の最終ブロッ クの測定值であるが，この值は溶接による残留応力のみ ならず鋼板圧延のさいの 素材残留応力も含むものであ る。軸方向の残留応力については下フランジにほぼ全域 にわたり圧縮応力が, また隅板下縁には引張力, さらに その上縁側では引張力が圧縮力に転ずる傾向がみられ る。全般的にこの種の溶接構造物として残留応力, 特に 圧縮成分の值は特に大きいとは考えられない。A-2 の手 孔周辺で圧縮応力がやや大きいのは孔控除による応力増 と推定する。断面方向の測定值については隅板に両端拘 束による張力の分布がみられる。以上の諸点から巨視的 な判定として, 隅板には引張力の残留応力が支配的であ ることからみても隅板の単板としての座屈安定に残留応 力が影響を与えるとは考えられないこと，下フランジ全 体の座屈耐力以前節の解析・実験結果からみて短柱に準 ずるので, 厚板フランジ内の多少の圧縮成分の残留応力 が問題になるおそれはないことなどの諸点があげられよ う。逆に隅板の軸方向引張成分の残留応力は, 正モーメ
ント領域の主桁ブロックにおいて, 隅板終端部のビード 周辺の局所的な集中応力発生の可能性を示唆している。 この観点から隅板終端部については,ビードを十分にま わすとともに，隅板端に半円の切欠きを設けて集中応力 の搪散をはかった。

\section{4. 主桁下フランジの高カボルト継手}

広幅員の二主桁橋では主桁下フランジは必然的に大型 化するが，極端な厚肉フランジは継手の設計に困難を伴 う。本橋のフランジ隅角部に隅板を設けたのは前記のと おり圧縮耐力の向上を期したこともあるが，もうひとつ の目的はフランジ板の板厚を抑える点にある。すなわち フランジ所要断面積の一部を隅板に肩がわりさせるとと もに，隅板下縁がフランジ板を軸方向に支持することを 利用して，フランジ板の幅をより広くすることを可能と した。継手の構造の概要を写真一2 亿示す。フランジ板の 端面はすべて機械切削され，圧縮継手ではフランジ板応 力の $50 \%$ はメタルタッチ面で直接応力伝達するとして 設計した。圧縮継手のみならず完成後引張力のみ作用す る継手についても端面切削を行ったのは，主桁の直線性 管理・キャンバー管理を目的としたものである。すなわ ちカンチレバー架設を基本とする本橋では, 主桁ブロッ クの取付けのさいブロック自重によって下フランジ端面 はみずから圧着する形となるから，端面直角精度は継手 部に㧍けるフランジの直線性を決定する重要な因子とな りらる。またキャンバー形状についても同じ理由からボ ルト孔を基準とするより切削端面を基準とした方がより 高い精度を期待できる。

継手の強度設計で考慮した事項は次の 2 点である。

（1）フランジ板相互の目違いに対する配慮：接合さ れる $2 つ の$ 主桁ブロックの間には, 桁高誤差や腹板部の ボルト孔誤差による鉛直方向の相対ずれ，フランジ板厚 の公差やフランジ板の溶接ひずみによるフランジ端面相

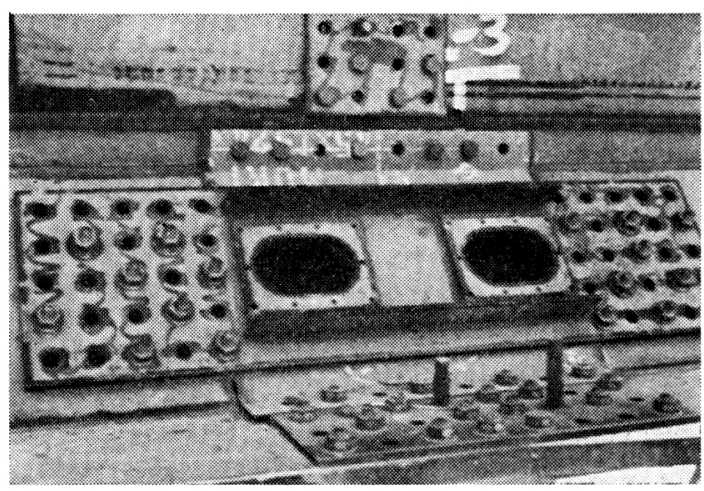

写真一2 圧縮領域における下フランジの高カボルト 継手例（工場仮組立の状況） 


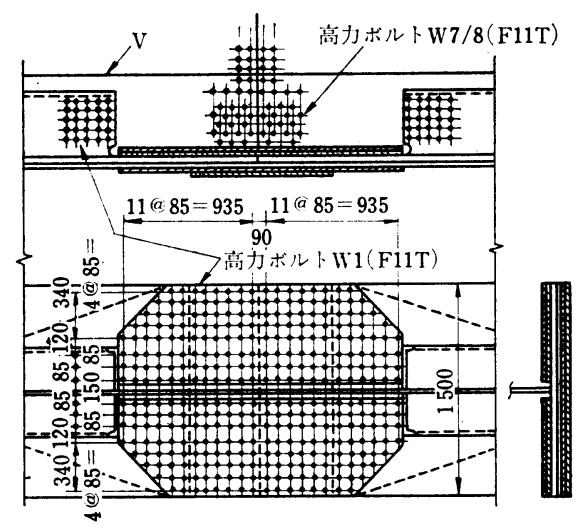

図一4引張領域における下フランジの高カボルト継手例

互の目違いがありらる。一般に部材の大型化に伴ってこ の種の目違いは増大傾向にあるとみる必要がある。そこ で文献 4）に報告した一連の実験の結果に基づいてフラ ンジ全厚の大きな継手については添接板を 2 枚重ねと し，多少の目違いがあってもすべり耐力が減少しない対 策を構じた。添接板の最大厚を $22 \mathrm{~mm}$ に抑え，それ以 上の厚さの添接板が必要な籄所では添接板を 2 枚重ねと して摩擦面に 対するなじみの向上をはかったものであ る。また工場製作時の腹板のけがきはすべて桁下端から 行い, 下フランジの目違いを最小に抑制した。

（2）菱形もしくは八角形のボルト配置に対する配 慮: 本橋のフランジ板は最大厚を $50 \mathrm{~mm}$ に抑えそれ以 上の厚さが必要な箇所はカバープレート1 枚を重ねた。 主桁全ブロックを通じて突合せ溶接は前章でも述べたと おり皆無である。結果的に引張フランジの場合孔控除に よる断面損失が大きくなることはやむをえないが，この 影響を極力避ける観点からボルト配置を検討すると菱形 に近い形状のものになる。極端な菱形配置はボルト相互 間に伝達力の不均一性を生じ，結果的にすべり耐力が低 下することを実験によって確認し（文献 4))，極端な菱 形形状のボルト配置を回避すると同時に，ボルトの配列 形状によっては念のためボルト総数を $10 \%$ 以上増加さ せた。

引張 フランジの高力ボルト継手の一例を図一4 に示 す。このほか全継手について閉断面の水密性について構 造・施工面で特に注意を払う必要があった。

\section{5. 鋼床版横リブのスカラップ周辺の応カ集中}

スカラップ周辺の応力集中の問題については, 日本造 船研究協会に設置された研究部会において広範な実験と 解析が大手造船会社によって行われ，応力集中による疲 労割れと座屈の問題が検討された（文献 5))。石川島播 磨重工業技術研究所ではこの実験と平行して, 有限要素
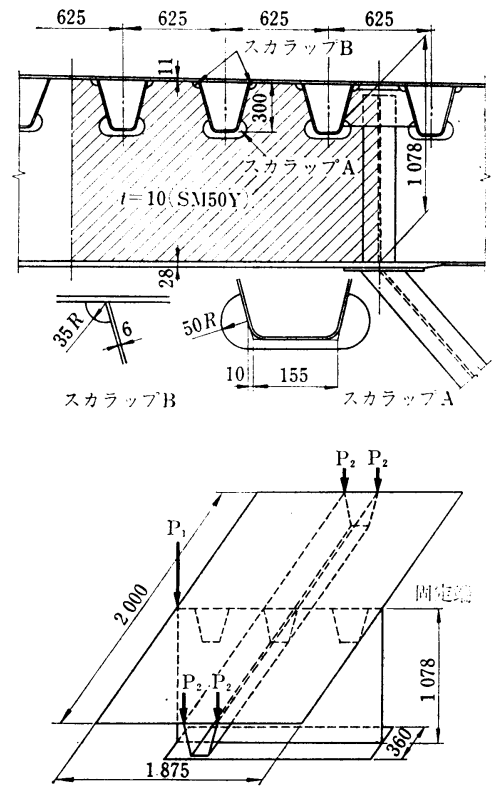

図一5 落目スカラップと解析モデル

法に基づく板構造解析用汎用プログラム ISTRAN/PL によってこの問題を 3 次元のモデルに置換し, 解析的に 実験結果とほぼ等しい確度で応力集中の状況を把握しう る手法を確認した。本橋の場合, 横リブの支間長が大き いこと, 横リブ高に比して縦リブ高が高いこと, などか らスカラップ周辺の応力集中の程度をこの手法によって 解析的に調查することにした。実際には 3 種類の形状の スカラップを比較検討したが, ここでは実橋に採用した 図一5 の形状についてその内容を要約する。横リブのせ ん断力の大きい斜線部分に注目し, 同図下のようにモデ ル化した。スカラップは縦リブ 3 本分をあけてあるが, 計算時間の都合上縦リブは中央 1 本のみ組んだ。モデル の支持条件はニーブレース直上部の縁端でデッキプレー トと横リブ縁端を固定し, 他の縁端はすべて自由端とし た。すなわち全体は片持ばりとなっている。荷重として はスカラップ周辺の応力が横リブせん断力のみならず緃 リブせん断力によって影響される点を考慮し，その影響 度判定も意図して,

荷重状態 I $: P_{1}=40 \mathrm{t}, \quad P_{2}=0 \mathrm{t} \quad \sum P=40 \mathrm{t}$

荷重状態 II $: P_{1}=0, \quad P_{2}=2.5 \mathrm{t} \quad \sum P=10 \mathrm{t}$

荷重状態 III : $P_{1}=30 \mathrm{t}, \quad P_{2}=2.5 \mathrm{t} \quad \sum P=40 \mathrm{t}$

の 3 種とした。図一6 に横りブ腹板のメッシニ分割を, また図一7 に算出された主応力を整理した結果を示す。 各荷重状態に対するスカラップAの左端部および右端部 の最大主応力は次のとおりである。

荷重状態 I : $-2950 \mathrm{~kg} / \mathrm{cm}^{2}$ (左), $+2450 \mathrm{~kg} / \mathrm{cm}^{2}$ (右)

荷重状態 II : $-480 "$ " ("), + $280 "$ " (")

荷重状態 III : $-2750 "$ " ("), +2750 " （"） スカラップ B の最大主応力はいずれも $800 \mathrm{~kg} / \mathrm{cm}^{2}$ 以下 


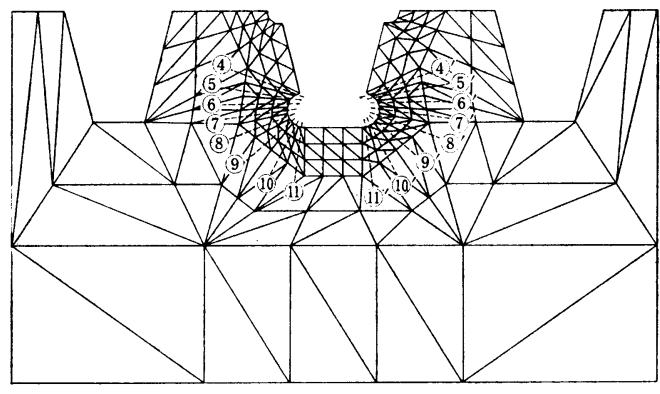

図一6 横リブ腹板のメッシュ分割図
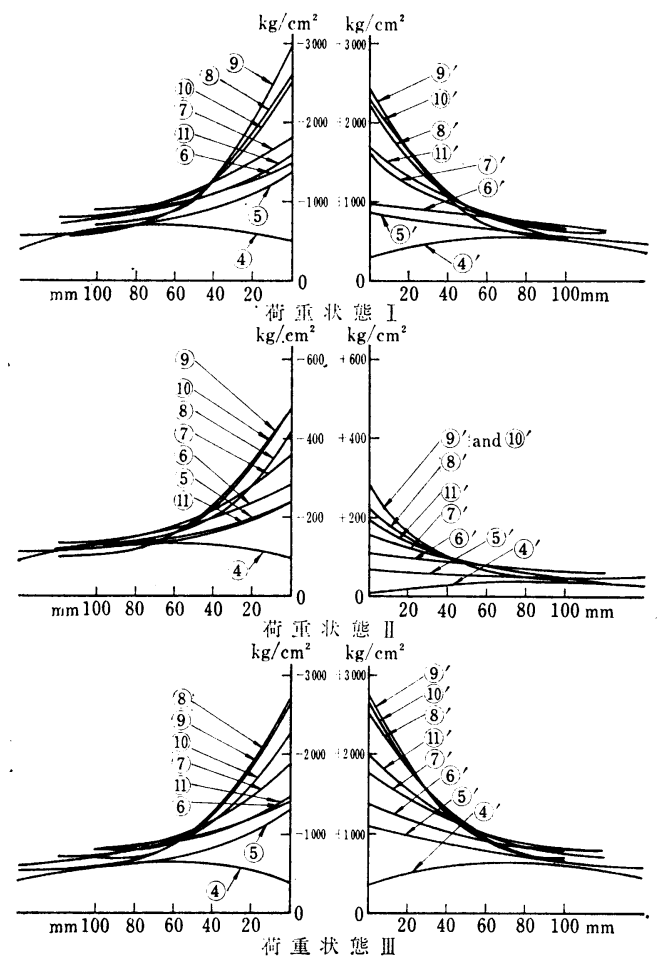

図一7 スカラップ $\mathbf{A}$ の各断面主応力

々小さい。以上の解析は実際の設計作業の途上で行った 関係上，荷重の大きさとしてやや安全側をみている。す なわち集中応力に支配的な影響を与えている着目断面腹 板せん断力は, 後出 8. に扔ける立体骨組構造解析から 計算すると, ニーブレースの存在などにより減少して死 荷重・活荷重・衝撃荷重計 $36.7 \mathrm{t}$ である。

結論としてスカラップAについては,

(1) 算出した引張応力はガス切断縁端を有する $\mathrm{SM}$ $50 \mathrm{Y}$ の疲労限 $2600 \sim 2800 \mathrm{~kg} / \mathrm{cm}^{2}$ にほぼ等しい值を 示すが，ここで検討したような荷重が発生することはま れである。

(2) 腹板板厚と圧縮応力をうけるスカラップ周辺自 由長の比からみて弾性限内の座屈はありえない。また圧 縮応力の最大值は局所的に集中していて平均応力はより
低い。などの諸点から安全と判定した。むしろ中空縦リ ブおよびスカラップBの存在により, 横リブ腹板とデッ キプレート間の隅肉溶接は事実上断続溶接の形になり, 大きな水平せん断力が発生するのでこれに対処する必要 があった。実施設計においては幅員方向に 4 枚あるデッ キパネルのうち, せん断力の大きい外側の 2 枚について はスカラップBを設けず，隅肉溶接の長さをできるだけ 長くすることにした。追記すれば，鎆床版溶接部の疲労 強度については設計活荷重の $50 \%$ をとって作用応力を 算出し, 西ドイツの鉄道橋設計基準 DV 848 に照らし て耐力の確認を行った。

\section{6. カンチレバー架設中の応カ測定}

二主桁橋の下フランジが圧縮力に対してもっともきび しい状態におかれるカンチレバー架設中の応力状態につ いて本橋の架設中現地測定したところを以下報告する。

架設中の応力測定の対象として選んだのは P-5 から 海上へ向って張り出すカンチレジーアームの基部である (図一8)。橋体ブロック長はすべて $18 \mathrm{~m}$ であるから， デリック・移動支持トラスなど架設器材はすべて $18 \mathrm{~m}$ を単位として前進していく。架設手順については文 献 6),7)に詳しい。現地測定に先立ってあらかじめ理論 計算によって架設各段階の発生応力を予測したが, カン チレバーアームの長さに応じて鋼床版有効幅が逐次変化 する関係上，図一9に示す手順で各段階における有効幅 を勘案しながら新規荷重による作用応力を算出し，これ を次々に加算していく必要があった。図一8に示す荷重 はすべて静荷重としての数值であり, 測定応力と対比す るための予測応力值はこの静荷重から算出した。しかし 実際の設計計算時にはクレーン関連基準を参照して, デ リックのジブおよび吊っている部材重量に対しては 1.2 , デリック本体については 1.1 の動荷重係数を乗じ,さ らに風荷重による影響も加算して安全率を照查した。こ

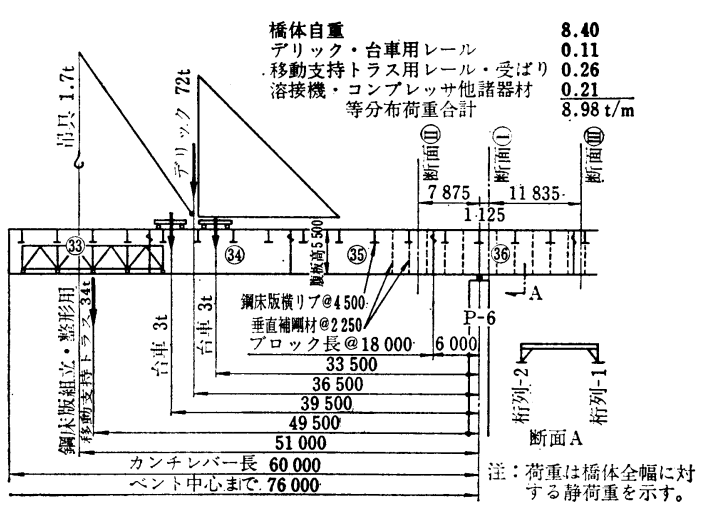

図一8 カンチレバーアーム諓荷状態 


\begin{tabular}{|c|c|c|c|c|}
\hline 休 & デリック & 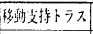 & 荷 状 哗 & 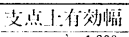 \\
\hline $\begin{array}{l}\text { フロック } \\
\text { (35) } \\
\text { 补材全械 }\end{array}$ & $\begin{array}{l}7 ロ ッ ” \\
\text { (36)上 }\end{array}$ & $\begin{array}{c}\text { ブロック } \\
\text { (35)ド }\end{array}$ & 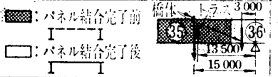 & 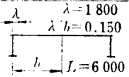 \\
\hline 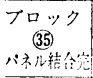 & 移動前進 & 移動崩進 & 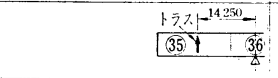 & $\begin{aligned} \lambda & \lambda=6492 \\
\lambda^{\prime} h=0.541 & \end{aligned}$ \\
\hline 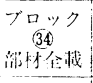 & 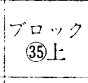 & 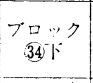 & 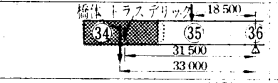 & $\begin{array}{l}\lambda=6492 \\
\lambda=0.541\end{array}$ \\
\hline 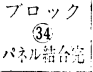 & 移聂游谁 & 移秙讨谁 & $\frac{-\left.32250\right|^{-1550}}{34 t}$ & \\
\hline 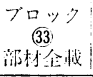 & & $\begin{array}{c}\text { プロック } \\
\text { (33)下 }\end{array}$ & \begin{tabular}{|l|l|l|} 
& $3655 \times 1$ & - \\
34 & 135 & 36 \\
$4950)$ & $\frac{36}{4}$
\end{tabular} & $-\lambda-\begin{aligned} \lambda & \lambda=8340 \\
\lambda & \lambda=0.693\end{aligned}$ \\
\hline
\end{tabular}

図一9 カンチレバー各段階の載荷状態（単位 $\mathrm{mm}$ )

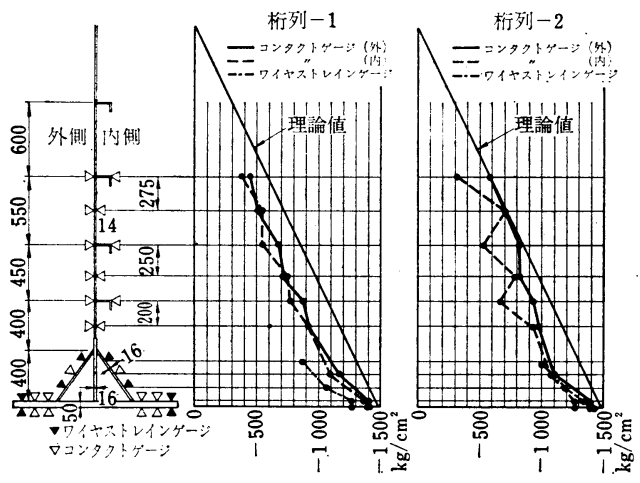

図一10 カンチレバー架設中の主桁の応力測定結果 (図-8 の断面 (I)

の設計計算における安全率としては AASHO 規定には 特に数值が明記された条文がないが, カンチレバー架設 はその途上において部材特に圧縮フランジに座屈を生じ ると次のつり合い状態がないこと，本橋工事の社会的意 義などを考慮して，AASHO 規定が完成後の橋体に対 して要求している安全率 $\left(\sigma_{\boldsymbol{p}} / \sigma\right) 1.82$ が架設中において もつね保持できることとした。測定は主桁下フランジ 周辺の圧縮応力作用值の確認を主眼とした。測定に 1 か 月近い長期を予想した関係から，測定方法はコンタクト ゲージ（STAEGER 社 BAM 型）を主体とし，一部に 比較照査の意味でワイヤストレインゲージ（協和電業製

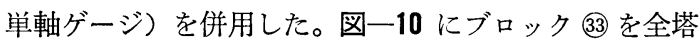
載した状態（図一8の状態）における測定結果を示す。 図一10 から次の諸点を読みとれる。

（1）全般に理論上の予測值よりやや值が低目である。

（2）腹板水平補剛材に曲げ応力が生じている。

（3）補剛腹板の応力分担にやや減退傾向が認められる。

（1）の原因として鋼床版有効幅の安全側の仮定による 誤差も考えられるが，一般に桁の上フランジ断面の増減 が下フランジの応力值に与える影響は小さく本橋につい て試算してもこの傾向は変わらないから, 主因はむしろ 下フランジ近傍に設けられている架設機器用レールとそ の受梁 (図一1 参照) が下フランジの応力の一部を分担
したことによるものと考える。(2) については两側の主 桁が同一傾向を示しているところから，水平補剛材が偏 心軸力を受けたことに 起因するとみてよい。図一10の 桁列-2 最下段の水平補剛材について測定值から水平補 剛材と腹板との合成断面に対する曲げモーメントを求 め, モーメント分布を垂直補剛材間 $(2.25 \mathrm{~m})$ で 2 次放 物線としてこの水平補剛材の面外たわみを概算すると， 面外たわみは内側へ向って $0.12 \mathrm{~mm}$ といら数值にな る。いずれにせよ量的に微少でありこの変形がおよぼす 二次的な影響は小さいとみてよからう。(3) は薄肉断面 の補剛腹板が初期不整などの諸因子によって, 本来補剛 腹板自身で分担すべき応力の一部を厚肉断面の下フラン ジ板に有がわりさせた結果とみられる。しかし本橋の橋 体の断面二次モーメントのなかに占める補剛腹板の断面 二次モーメントの比率は 7 8\% と僅少であり, このた めに生じる下フランジ板の応力増加量は小さい。以上が 主桁の応力測定の概要である。ブロック (32) 塔載時下フ ランジに約 $2000 \mathrm{~kg} / \mathrm{cm}^{2}$ の応力が測定されたが, 架設 作業を進行中の測定であること, カンチレバー先端のべ ント仮受けがすでに開始され外力状況が明確でないこと から報告を省略する。また鋼床版デッキプレートの応力 測定も主析測定に平行して行ったが, 当時デッキ面は部 材・器材の仮置場ないしは運搬路に使用された関係上ほ とんど常時大小の床組応力の混入が不可避であったた め，信頼すべき測定值は採取不可能であった。さらに下 フランジを支持しているニーブレースの応力測定, 圧縮 応力増大による腹板の面外たわみ (ヤセ馬) 変化量の測 定なども平行して行ったが, 架設全工程を通じて特記す べき応力発生あるいは変化を認めなかった。カンチレ バー先端のたわみは予測值に近く, 風による振動を人体 に感じることはほとんどなかった。

\section{7. 支承と伸縮継手}

後述する載荷実験結果によっても明らかなとおり, 二 主桁橋に用いられるような大支間の鋼床版のたわみは版 の荷重分配作用によって支間の割には小さ目である。し かし荷重分配の良くない版の終端部つまり橋端において は，版のたわみは過大になりがちである。当然大型の端 横桁を設ける必要があるが，端横桁のたわみはその大き さが設計示方書の要求する $\delta / l$ 制限内にあるかどうかと いうことよりも，この場合むしろ路面走行性および伸縮 継手の保全に対する配慮からよりきびしく照査する必要 がある。たとえば本橋の固定端の橋台部では伸縮継手の のる支間 $24 \mathrm{~m}$ の端横桁をその支間中央で摇柱によって 支持し (写真一3)，たわみを最少に抑制する処置をとっ た。また可動端には同じくたわみを抑える観点から，桁 


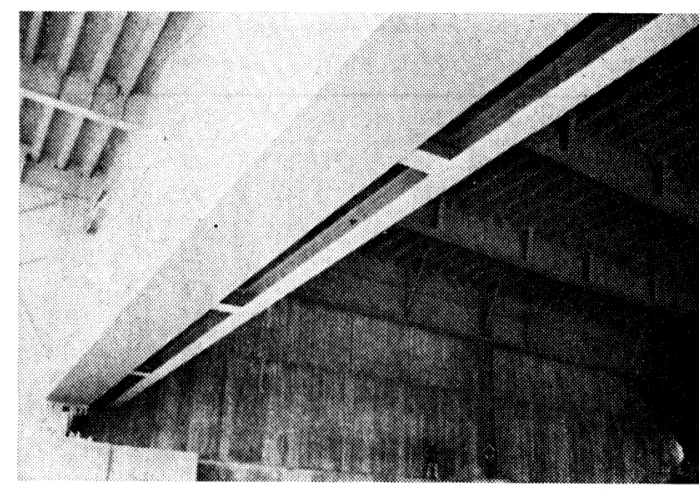

写真一3 固定端端横椼の摇柱による支持

高 $2.6 \mathrm{~m}$ の箱断面横析を設けてこの上にのる伸縮継手を 保謢することが必要であった。こうしたことから一般的 にいって, 二主桁橋は極力連続桁形式とし版の構造的な 不連続性を最小にとどめることが望ましい。本橋の全長 $822 \mathrm{~m}$ を 8 径間連続構造としたのは，ひとつにはこの観 点によるものである。本橋の可動端における移動量の設 計值は次のとおりである。

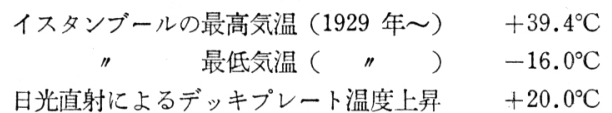

$75.4^{\circ} \mathrm{C}$

$$
\begin{aligned}
& 75.4 \cdot 12 \cdot 10^{-6} \cdot 822 \cdot 10^{3}=745 \\
& \text { 上部工据付誤差打よび下部工移動〜 } \frac{80}{825 \mathrm{~mm}}
\end{aligned}
$$

結局可動支承の最大移動量は端支点で $\pm 412.5 \mathrm{~mm}$ ，最 大反力は中間支点で $1466 \mathrm{t}$ となった。可動支承として 西ドイツの F. Kreutz 社の1本ローラー形式のものを 購入使用した。ローラーおよび支圧版は 13 クローム鋼 を中心部まで焼入れしたものである。伸縮継手の設計移 動量は P C 橋の伸縮量を加えて $\pm 475 \mathrm{~mm}$, 西ドイッ Demag 社の N-Type（全重量 $95 \mathrm{t}$ ）を購入使用した。 橋脚 P-8 上で測定した支承移動量と気温・橋体温度と の関係を 図一11 に示す。まず横桁は直射日光の影響を 受けない部材として温度測定したものであるが，早朝は 気温と同じく以後は気温変化に多少の時差で追随してい る。一方デッキ裏で測定したデッキプレートの温度が朝 方気温より低目であるのは，夜間に冷却した舗装および 中空断面縌リブ内の冷気の影響による。夕方のデッキプ レートの温度下降が遅いのは逆にこれらの保温効果によ るものである。次に支承の移動量と橋体温度との関係で あるが, 主桁外面への日光直射の影響を考えると, 図一 11 のデータから画者の相関性を理論的に追跡すること には無理がある。そこでひとつの目安として，日光直射 の影響を常時受けているデッキプレートの温度変化と， 日光直射の影響がなく気温変化のみに影響されている横 桁の温度変化とをそれぞれ鋼橋全長の伸縮量に換算して

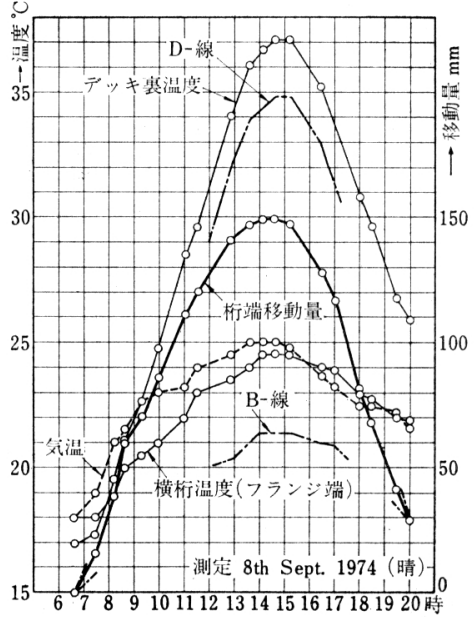

図一11 P-8における桁端移動量

みたのが，図一11 中に示した D 線および B 線である。 两線の值を実際の支承移動量と比較すると，実際の移動 量は両線間を $63: 37$ で内分する形で $\mathrm{D}$ 線寄りにあり, 支承移動量に対してデッキプレートの温度がより支配的 であることを示している。一方全橋体断面における鋼床 版と主桁の断面比率を計算すると, 平均比率はほぼ 6 : 4 であり上記比率とほぼ対応する形になっている。この ように広幅員二主桁橋では日光直射によるデッキプレー トの温度上昇はかなり直接的に全橋体の伸縮に影響する ので，支承および伸縮継手の設計にさいしてこの点に留 意する必要がある。本橋の 8 月上旬の測定例としてデッ キ裏で $48^{\circ} \mathrm{C}$ の記録があるが，継続的にデータ採取を行 ったわけではないので最高值とはいえない。Demag 社 の報告によれば舗装下のデッキプレートで $63^{\circ} \mathrm{C}$ という 計測例もあるようである。完成橋梁が未舗装で夏を過ご す場合には, デッキプレートは予測以上の高温に達しら るので注意を要する。二主桁橋は桁間隔が広いので当然 横方向の橋体伸縮も考慮する必要がある。本橋の場合横 方向の全伸縮量は $75.4 \cdot 12 \cdot 10^{-6} \cdot 24 \cdot 10^{3}=21.7 \mathrm{~mm}$ であり，下部工の横伸縮を考虑しても支承の横方向遊間 だけでは吸収できない。そこで橋脚をフレキシブルな独 立柱とし温度応力の拘束を極力さける構造とした。

\section{8. 載荷実験}

本橋の載荷実験はボスポラス海峡の吊橋と並んでトル コ政府の指示により行われたものである。内容は設計荷 重満載による主桁の耐力検定, 静的・動的荷重による橋 体各部の挙動の測定であった。以下静的実験についてそ の結果を要約する。測定詨象としては作業上の便, 車輌 の台数限度などから海上部の最大径間部を避け，陸上部 の P-2 から P-3 に至る $108 \mathrm{~m}$ の径間を選定した。 


\section{（1）荷重の選定と計量}

実験当時本橋取付道路の舗装工事が進行中であり, 舗 装業者の使用しているトラックを夕刻後に限って借用す ることが可能であった。車種は全 5 種であるが, これら の全車種はトルコの標準設計に基づいて製造されたもの であり, 細部付属品は別として主要寸法と軸重はまった く同一である (図一12)。幸いに本橋橋端至近距離に広大 な骨材貯蔵場がありローダーと計量器も常時配置されて いたので, このトラックに砂利を積載して一台当り総重 量 $15 \mathrm{t}$ の実験用荷重として使用した。計量器の検定は 事前に行った。すなわち無載荷トラックー台をボスポラ ス道路計画の工事用に設けられていた 3 箇所の計量所を 順回し, 計 3 台の測定值を比較した。結果は $6670 \mathrm{~kg}$, $6675 \mathrm{~kg}, 6700 \mathrm{~kg}$ で実験用としていずれも精度は十分 と判定した。実際に使用した計量器は前記骨材貯蔵場の もので検定時 $6670 \mathrm{~kg}$ を示した計量器である。
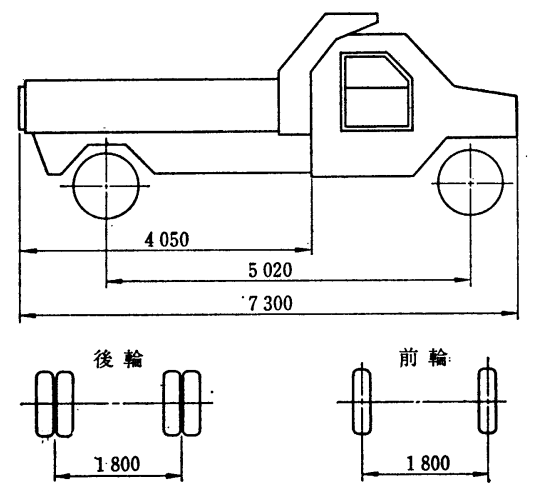

図一12 実験用荷重主要寸法図

車輪台数としてはまず主桁測定用として 42 台を用い た。支間中央の正モーメントが設計計算值とほぼ同等に なるように台数をきめたものである。

設計荷重 : 衝撃を含を活荷重モーメント $=3365 \mathrm{t} \cdot \mathrm{m}$ 実験荷重 : 静荷重による曲げモーメント $=3530 \mathrm{t} \cdot \mathrm{m}$

すなわち曲げモーメントに換算して設計荷重の $5 \%$ 増し の荷重をのせた。この 42 台のトラックの計量は総重量 についてのみ行った。実験の精度確保のみならず安全上 の理由もあって, 重量計測時には許容誤差範囲を明確に し,これをはずれるものについては調整を行った。最終 計測值を表一1 (1) に示す。次に床組測定用の荷重とし ては各車線 1 台計 6 台のトラックを用いた。この場合の 重量計測は前輪軸重, 後輪軸重, 総重量の 3 段階につい て行った。最終計測值を表一1 (2) と示す。

\section{（2）測定箇所之測定方法}

応力測定箇所を 図一13 に示す。人員・器材をすべて
表一1 臷荷用荷重の最終計測值（単位 $\mathrm{kg}$ )

(1) 主椼計測用車両重量計測值

\begin{tabular}{c|c|c|c|c|c}
\hline No. & 重 量 & No. & 重 量 & No. & 重 量 \\
\hline 1 & 15260 & 15 & 15540 & 29 & 14670 \\
2 & 15430 & 16 & 15400 & 30 & 15220 \\
3 & 15300 & 17 & 15360 & 31 & 15520 \\
4 & 15400 & 18 & 14350 & 32 & 15100 \\
5 & 14600 & 19 & 14850 & 33 & 14870 \\
6 & 14590 & 20 & 14330 & 34 & 14800 \\
7 & 15200 & 21 & 14760 & 35 & 14980 \\
8 & 14980 & 22 & 15430 & 36 & 15150 \\
9 & 15220 & 23 & 14920 & 37 & 15200 \\
10 & 15070 & 24 & 14460 & 38 & 15150 \\
11 & 15270 & 25 & 14800 & 39 & 15300 \\
12 & 14900 & 26 & 14730 & 40 & 14560 \\
13 & 15410 & 27 & 14980 & 41 & 15390 \\
14 & 14700 & 28 & 15090 & 42 & 15000 \\
\hline
\end{tabular}

計 $631240 \mathrm{~kg}$ (平均 $15030 \mathrm{~kg} /$ 台)

(2) 床組計測用車両重量計測值 第 1 日目使用荷重

\begin{tabular}{c|r|r|r}
\hline No. & 前輪軸重 & 後輪軸重 & 全体重量 \\
\hline 1 & 3240 & 11320 & 14650 \\
2 & 3890 & 11540 & 15400 \\
3 & 3790 & 11480 & 15370 \\
4 & 3670 & 11580 & 15340 \\
5 & 3480 & 11560 & 15140 \\
6 & 3410 & 11200 & 14670 \\
\hline 計 & 21480 & 68680 & 90570 \\
\hline 平均 & 3580 & 11450 & 15100 \\
\hline
\end{tabular}

第2 日目使用荷重

\begin{tabular}{c|r|r|r}
\hline No. & 前輪軸重 & 後輪軸重 & 全体重量 \\
\hline 1 & 3480 & 11470 & 14998 \\
2 & 3740 & 11340 & 15150 \\
3 & 3834 & 11480 & 15380 \\
4 & 3640 & 11480 & 15180 \\
5 & 3580 & 11502 & 15150 \\
6 & 3520 & 11470 & 15080 \\
\hline 計 & 21794 & 68742 & 90938 \\
\hline 平均 & 3630 & 11457 & 15160 \\
\hline
\end{tabular}

日本から調達した関係上測定点数に制約があったので, 下記の趣旨によって測定点の選定を行った。まず主桁に ついては正負の曲げモーメント領域各 1 断面について応 カの大きい下縁側を測定する。次に鋼床版横りブについ ては横リブ自身の曲げ変形によるニーブレースおよび主 桁下フランジの応力挙動も測定する。この場合横力に対 する下フランジの弹性支持強さは支承に近い箇所と支間 中央では異なるから, 主桁同様断面 1 および 12 につい て測定を行う。荷重は断面 1 上から断面 12 上に $4.5 \mathrm{~m}$ きざみに逐次移動させ, 順次測定を行うことによって, 影響線の形で鋼床版の荷重分配性状を把握する。最後に 鋼床版縌リブについては測点を最少限に抑え支間中央部 の 1 本だけについてその下縁応力を測定する。綎リブを 精密に測定するためには着目縦リブと輪荷重との位置関 係の厳密な管理が前提となるが, 舗装ずみの橋面表裹の 位置関係把握に困難を予想したこと, むしろ部材が大型 で測定上の問題点の少ない横リブに測定点を集中し, 横 リブの測定点と理論值との対比を媒介として縦リブの挙 動を推定する方が容易と判断したこと, などが縦リブ測 定点を最少限に抑えた理由である。以上が測定点選択趣 旨の概要である。応力測定には（株）東京測器製ワイヤ ストレインゲージ WFLA-3-11 (単軸)を用いた。たわ み測定箇所を図一14 に, 測定器を写真一4に示す。こ 
のたわみ測定器は早稲田大学堀井研究室によって本実験 のために製作されたもので, $160 \mathrm{~m}$ までの大たわみをダ イヤルゲージ同等の精度で測定可能である。一端をピン 支持された $400 \mathrm{~mm}$ 長のレバーの他端でたわみをとら え, 変位量をピン近傍で $1 / 20$ に縮小したところに隣青 銅の板ばねを連結し，板ばね表裏のひずみをワイヤスト
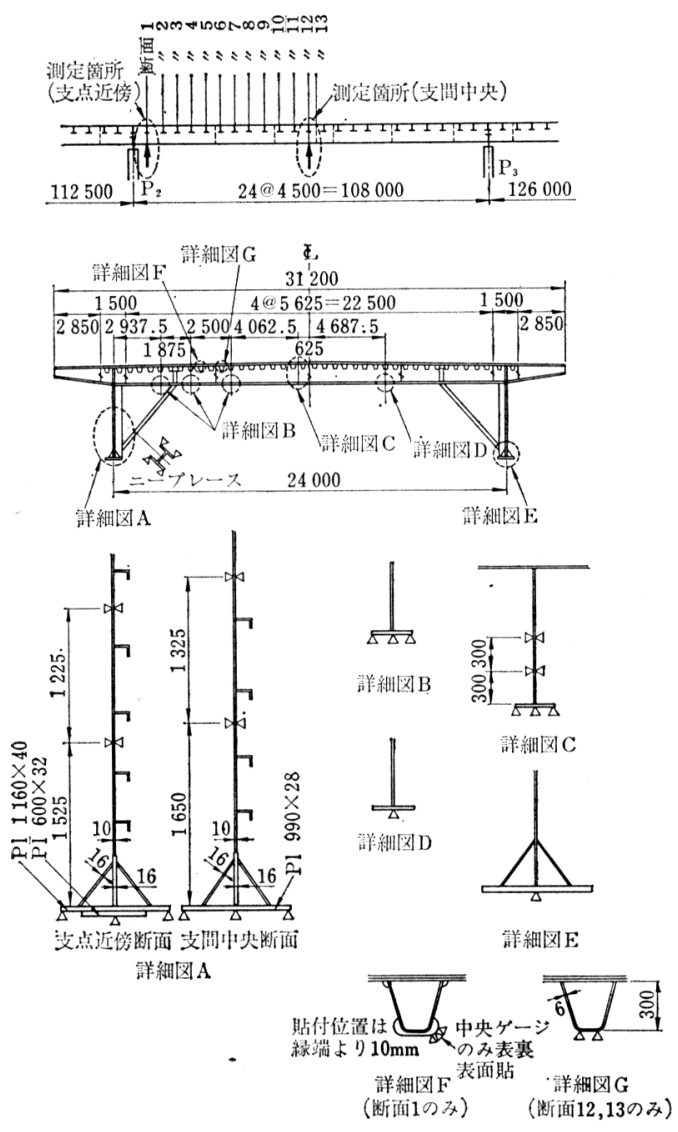

図-13 静的実験の応力測定箇所

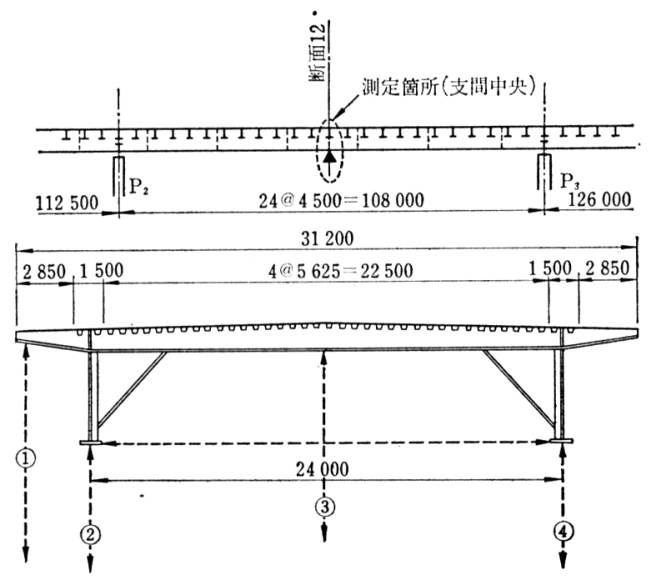

図一14 静的実験のたわみ測定䓢所
レインゲージで測定するのがこの测定器の原理である。 個々の測定器は本実験前にキャリブレートされ, ひずみ とたわみとの関係を示す特性曲線が淮備されていた。荷 重の載荷位置を図一15１6 に示す。トラックを極力精 確な位置に置くために, 実験に先立って舗装面にガムテ ープで十字型の印を設け, 各車の後輪をその上に位置さ せた。これらの静的実験は 1974 年 7 月末連続 3 日にわ

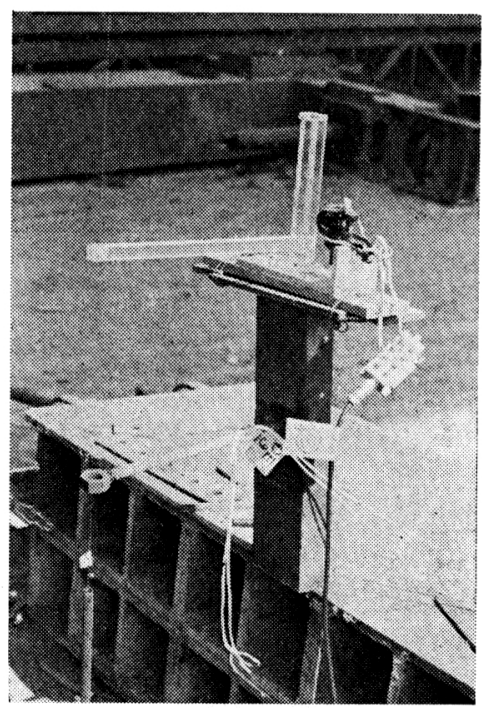

写真-4 大たわみ測定器

断淌No. $\quad 12345678910111213$ 栈话状黛 $L-123456789101112$ hthththt.th

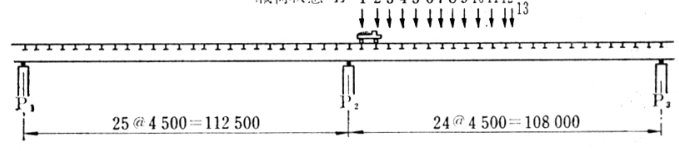

注:

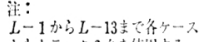

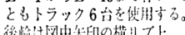

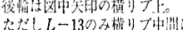
後滀它せる。

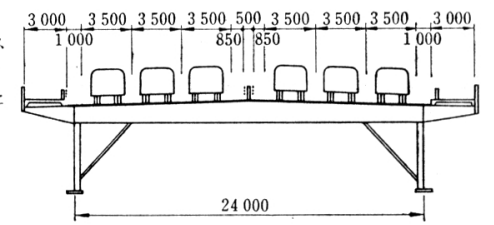

図一15 床組測定を主眼とした荷重載荷 L-1 L L-13

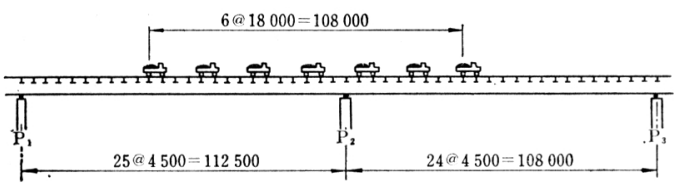

洼: 計42台のトラック老期用方る。

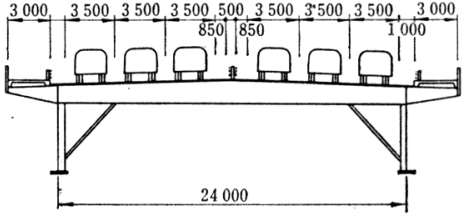

図一16 主桁（一M) を主眼とした荷重載荷 $\mathbf{L}-14$ 

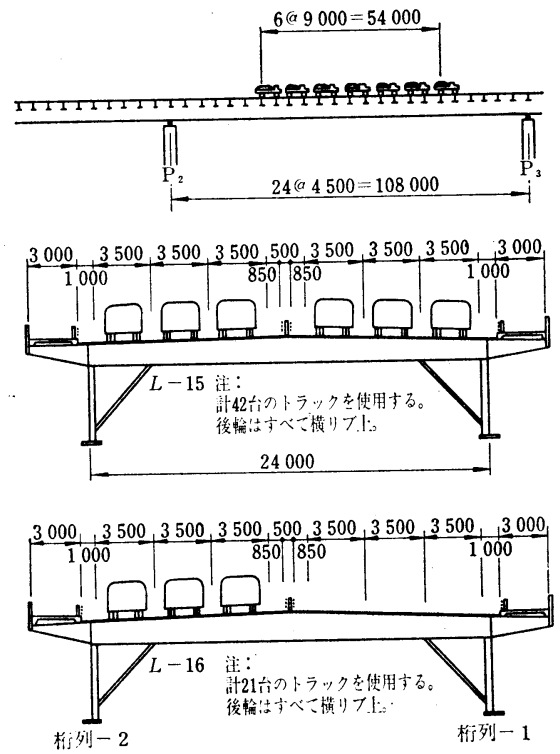

図一17 主桁 $(+M)$ を主眼とした荷重載荷 L-15, 16

たってすべて日没後行われた。測定は原則的に 2 回ずっ 行った。採取した生データは即日トルコ政府に提出され 別途検討をうけた。

\section{（3）応力とたわみの理論值}

主析の理論値算出については特筆すべきことはないの で内容報告は省略するが, トラック荷重の主桁への配分 をいわゆる 1-0 法で行ったこと, 偏載荷重 (L-16) に よる曲げねじりで主桁下フランジに生ずる横曲げ応力の 計算值は $\pm 50 \mathrm{~kg} / \mathrm{cm}^{2}$ 以内であることのみ付記する。本 橋の鋼床版の設計は米国 AISC の Design Manual に よって行ったものであるが, このさいニーブレースの存 在は無視されている。この仮定は鋼床版にとっては安全 側のものであるけれども，実際にはニーブレースが働き さらに主桁下フランジが横曲げをうけることは明らかで ある。この観点から設計時すでにニーブレースと主桁を 含む全断面系の立体的な応力挙動を別法によって照査し た(文献 1))。載荷実験にさいしても測定值と理論值の対 比を目的として, 当時と同様の手法でさらに詳細に理論 解析を行った。橋桁を 3 径間連続の骨組構造に置換し, トラックの各輪荷重を集中荷重として載荷したものであ る。前・後輪間距離は便宜的に横リブ間隔に合わせ 4.5 $\mathrm{m}$ とした。図一18 にその骨組構造の一部を示す。繸リブ の本数と配置は実際の構造物と相違するが, 床版単位幅 当りの縦りブの曲げ剛性およびねじり剛性は実際の構造 物と等価になるように配慮されている。ここで明記する 必要があるのは, この解析はあくまで床組構造に着目し て行ったもので, 主妳の理論值算出には無縁なことであ

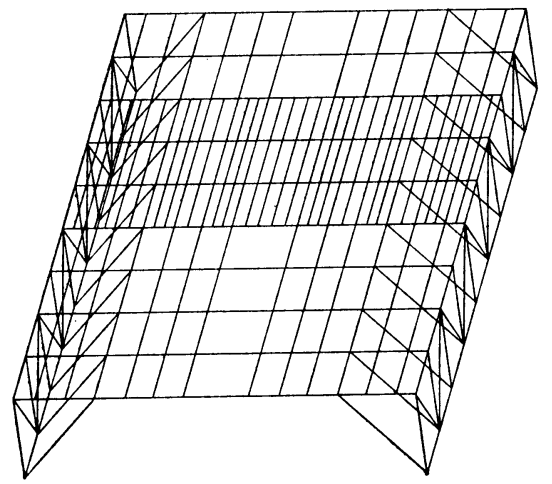

図一18 床組の立体解析のための骨組梓造の一部

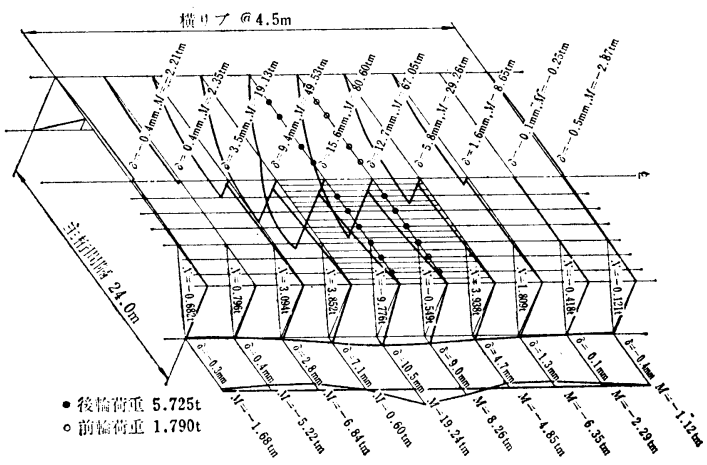

図-19 P-2 P-3 間の立体骨組系の理論解析値

る。換言すればトラスに置換された主桁は床組の立体解 析のための境界条件を与えるものである。図一19 に解 析結果の一部を示す。

\section{(4) 測定結果と考察}

図一20 22 に主桁応 力測定值を示す。理論值 に比して実測值が小さい のは, 架設中の応力測定 と同じく台車受梁の協同 作用が主因であろう。架 設時の移動足場は完成後 の橋标の検査車として恒 久的に使用されることに なったので, 受梁とレー ルもそのまま残されたも のである。下フランジに はニーブレースの軸力に よるものと思われる横曲 げがみられる。これらの 横曲げが後出 L-1, 12 す

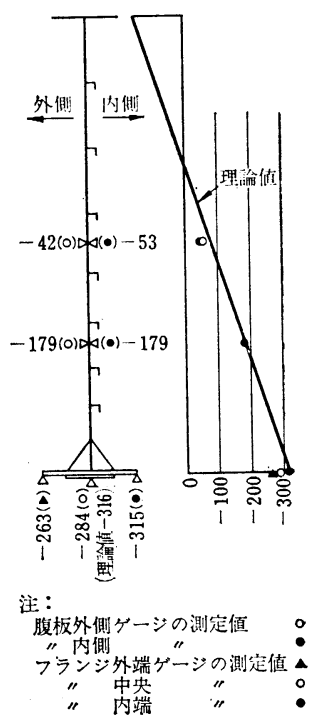

図一20 L-14 載荷による断面 1 (支点近傍) 主桁応力 (単位 $\mathrm{kg} / \mathrm{cm}^{2}$ ) 


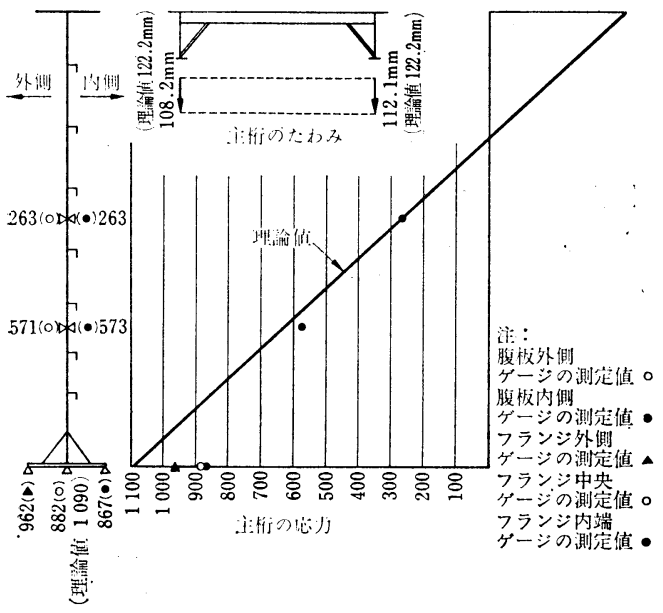

図一21 L-15 載荷による断面 12 (支間中央) 主桁応力と たわみ（特記なき単位 $\mathrm{kg} / \mathrm{cm}^{2}$ )

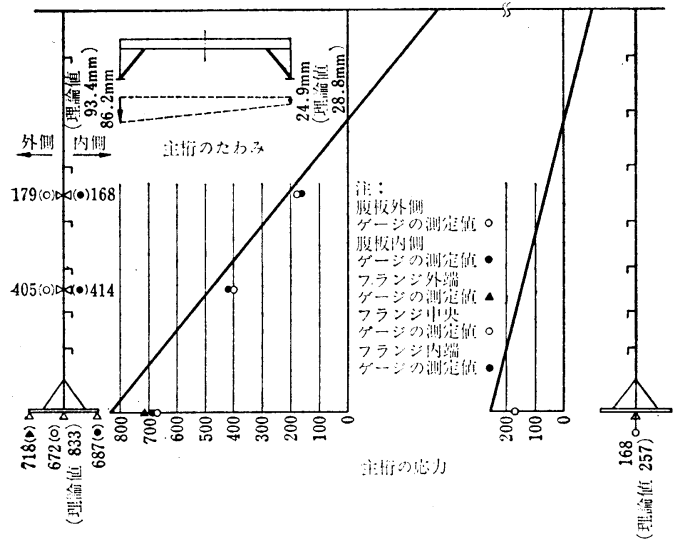

図一22 L-16 践荷による断面 12 (支間中央) 主桁応力と たわみ（特記なき単位 $\mathrm{kg} / \mathrm{cm}^{2}$ )

なわち測定点上に集中荷重（各車線にトラック1台，ト ラック計 6 台）を載荷した場合より小さいのは，この場 合荷重が着目点直上だけでなく前後方向に広く分布して いるため, 下フランジの横たわみも前後方向に分布し, 局所的な横曲げがむしろ緩和されたものであろう。L-16 の左右主桁の鉛直たわみの合計は L-15 の左右主桁の鉛 值たわみの平均値にほぼ一致している。路面上の活荷重 を 1-0 法により各主桁へ 分配することの妥当性が 裹付 けられている。次に鋼床版であるがまず横りブ・ニーブ レース関倸の測定值を 図一23 26に示す。各図とも着 目点固定, 荷重移動であるから影響線の形になってい る。横リブの測定值として支間中央部でなくやや側方 (図示) の測定值を示した。支間中央部は高力ボルトに よる現場継手が，その両側方にはフランジ付き垂直補剛 材があり，やむをえず下フランジ断面変化広の板厚の大 きい側で測定した。結果として理論值に比して測定值が

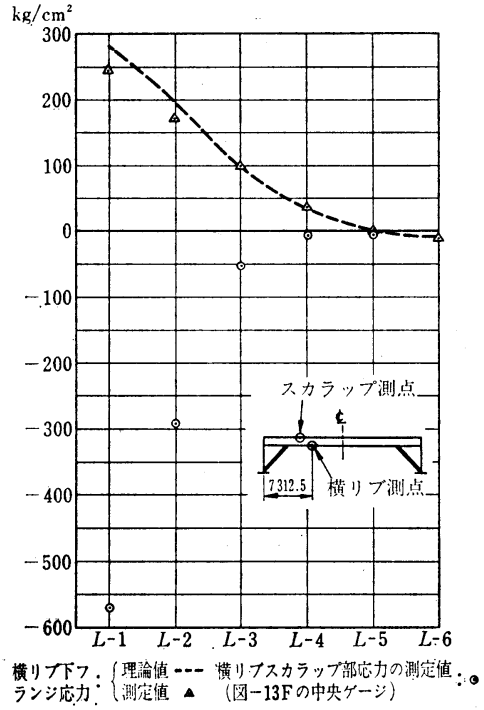

図一23 L-1～6 載荷による断面 1 (支点近傍) 測定値 その1

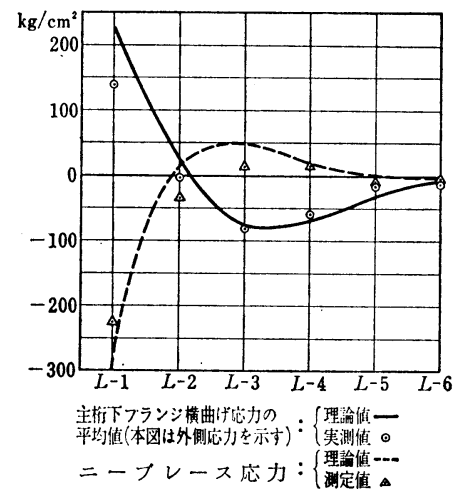

図一24 L-1 6 載荷による断面 1 (支点近傍) 測定值 その 2

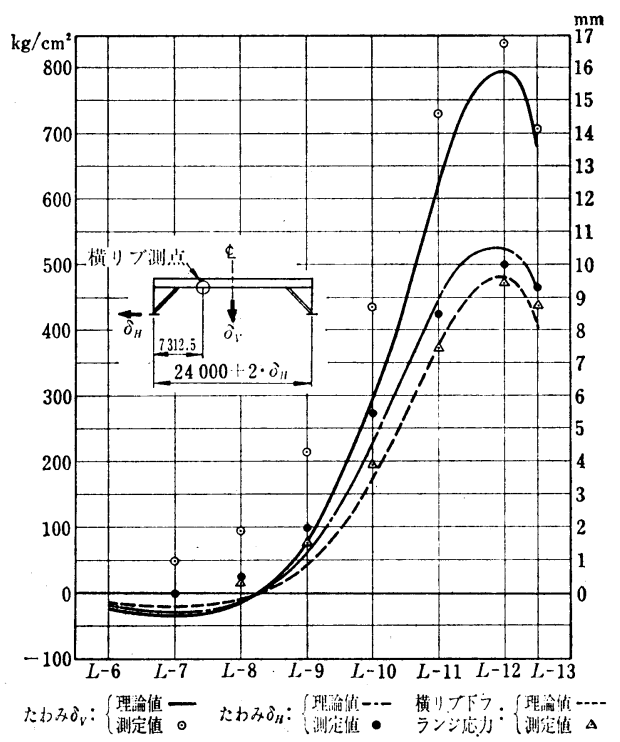

図一25 L-6〜13 践荷による断面 12 (支間中央) 測定值 その 1 


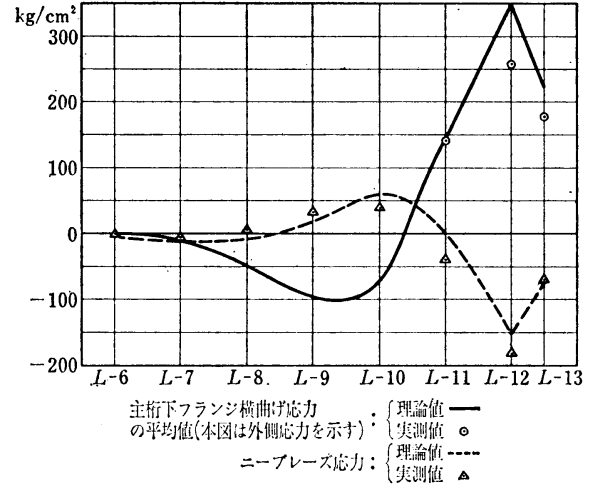

図一26 L-6 13 載荷による断面 12 (支間中央) 測定值 その 2

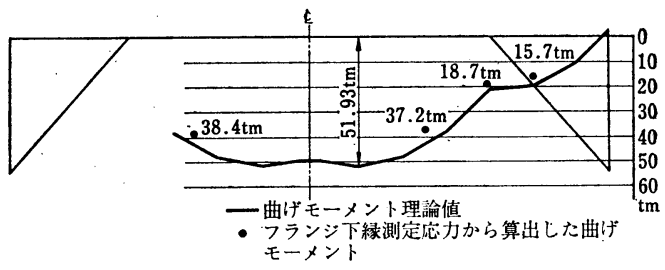

図一27 L-1 載荷による支点近傍横りブ曲げモーメント

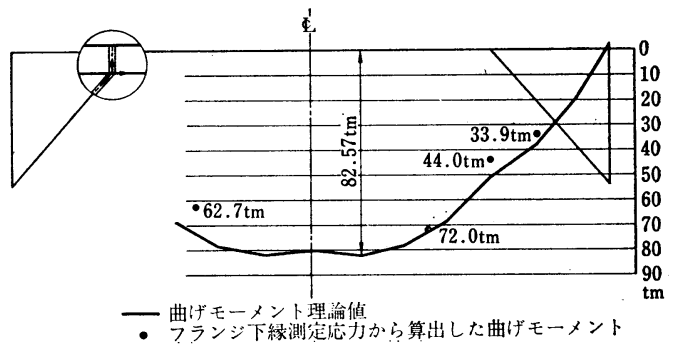

図一28 L-12 載荷による支間中央横リブ曲げモーメント

大幅に過少となるなど，この断面変化部の測定値は若干 の疑問を残したので，信頼性のより高い側方の測定值を 示したものである。ニーブレースの軸力は主桁下フラン ジの側方変位拘束の大きい断面 1 に执いてより大で，軸 カにして $14.3 \mathrm{t}$ である。必然的に断面 1 の横りブ応力 は断面 12 より小さい值を示している。図一27, 28 に横 リブの下フランジ応力測定值から算出した曲げモーメン 卜を理論值と対比した。支間中央部については前記の理 由からデータを省略したが, その測定值ならびに推定補 正值については文献 8）にやや詳しく述べたので参照さ れたい。支間中央部で曲げモーメント理論值がやや凹に なっているのは, 中央分離帯近傍に輪荷重がない上に， たわみの大きな支間中央で縦リブを経由して荷重分配が 特に大きいためである。ニーブレースの軸力は横リブに 水平分力として圧縮軸力を与えるが, 図一23, 25 および 図一27，28の理論值にはこの影響は考慮されていない。
この影響は横リブ全断面に対し最大 $-10 \mathrm{~kg} / \mathrm{cm}^{2}$ 程度で あるが, ニーブレース連結部近傍では局所的にやや大き いかも知れない。横リブスカラップ周辺の応力は測定值 のみを示した。骨組系によるこの部分の横リブ断面のせ ん断力は $9.5 \mathrm{t}$ である。測定応力を理論值と厳密につき 合わせることは困難であるが，巨視的に 5. の検討結果 と対比しらる。横リブの支間中央のたわみは $16.7 \mathrm{~mm}$, $\delta / L=1 / 1430$ である。横リブの桁高に比したわみが小さ いのは, 鋼床版の橋軸方向への大幅な荷重分配によるも のであり, 広幅員二主桁橋の床組構造のひとつの特長と いえる。断面 12 の測定值が理論值に比して全般に0に 向っての収㪘がおそいのは, デッキプレートの膜効果に よるものと推定する。その場合デッキプレートの張力に 対し反力として横リブに圧縮軸力が生じていることにな るが, 弾性理論で捉えうる範囲外なので推定の域を出な い。次に主析の下フランジを断面 12 についてみると, $10.5 \mathrm{~mm}$ 側方へ変位すると同時に $\pm 257 \mathrm{~kg} / \mathrm{cm}^{2}$ の横曲 げを二次応力として生じている。前述したとおりこの横 曲げは設計荷重満載の場合逆に減少するので実際上の問 題はないと考えるが，二主桁橋設計上のひとつの留意点 であろう。以上が横リブ・ニーブレース関連の測定結果 である。次に繸リブ下縁の測定応力を図一29に示す。主 桁上フランジとしての圧縮応力を含むものであり, 測定 点を遠ざかっても0に収㪘しないのはその影響である。 この縦リブの測定值をさきの骨組系による理論計算值と 対比させることは不可能である。骨組系における縦リブ は鋼床版単位幅当りの曲げ剛性とねじり剛性を等価に置 換したもので繸リブ本数まで合わせていないこと，骨組 系における縦りブはおのおのが独立した棒でありデッキ プレートの曲げ岡性による縦リブ相互間の荷重分配が考 慮されていない(文献 9) p. 50, $\mu=1$ に相当)ことなどが その理由である。そこで文献 9) の Pelikan-Esslinger の

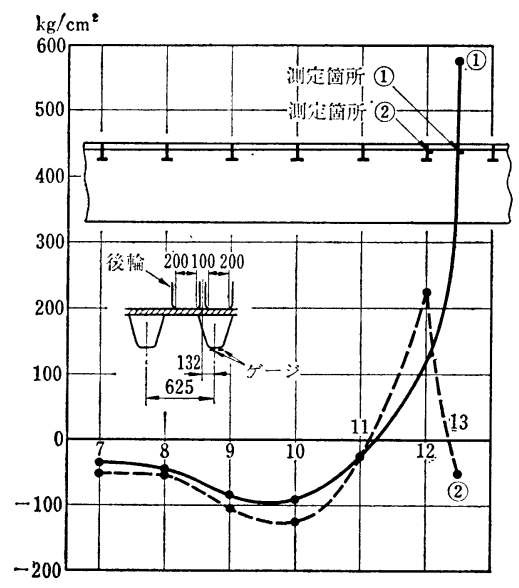

図一29 L-7〜13 載荷による支間中央断面付近 縦リプ下緑測定応力 


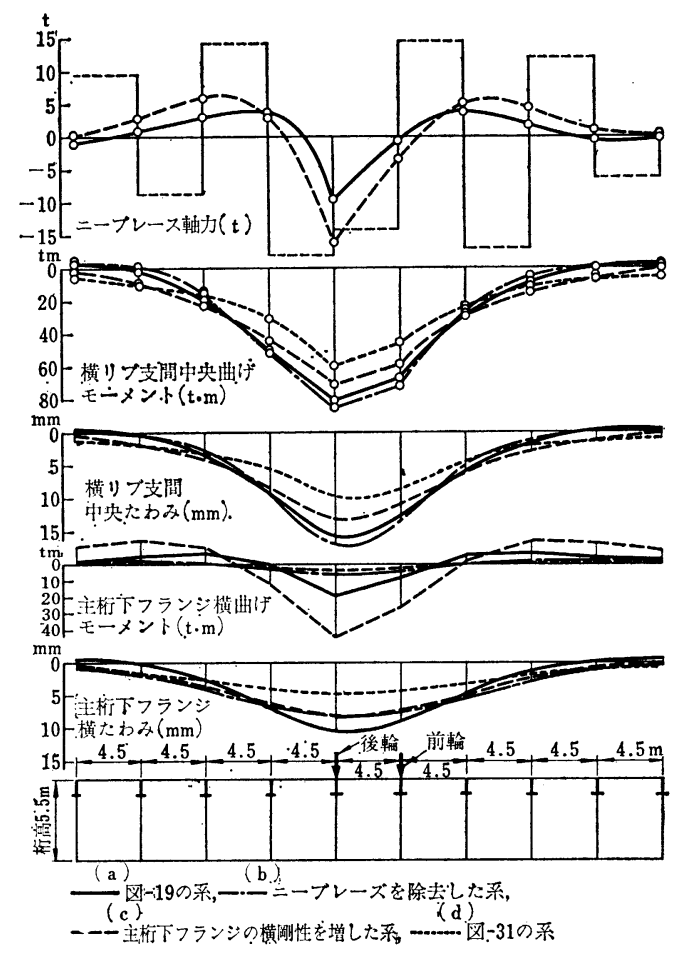

図一30鋼床版の支持条件を変えた各種系の 性状比較 (理論值)

原式にさかのぼって実験荷重に対する測点箇所 (1) (図一 29）の綎リブ下縁応力を精算した結果, $+717 \mathrm{~kg} / \mathrm{cm}^{2}$ の 值がえられた。このさい輪荷重の縦リブ反力はデッキプ レートを剛支承上の連続ばりとして求めたものである。 この点の主桁としての応力は L-7 の測定值からみて約 $-100 \mathrm{~kg} / \mathrm{cm}^{2}$ と推定されるから, 理論值と測定值はほ ぼ対比しうるものである。以上が測定結果の要約であ る。最後に 図一30 に次の各種骨組系の理論解析值の比 較を示す。

(a) 図-19 (原系) の理論值

(b) 原系のニーブレースを除去した系の理論解析值

(c) 原系の主桁下フランジの横方向断面 2 次モーメントを 5.3 倍に増した系の理論解析值

（d） 原系のニーブレースを図一31 のようにトラス状に組み 替えた系の理論值

(b) は原系におけるニーブレースの役割を明らかにす る意味で, 原系の各要素は変えずにニーブレースのみを 除去した場合の理論值を算出したものである。原系に比 して大きな差はないが鋼床版の荷重分配にやや劣化が認 められニーブレースが荷重分配に関与している事実を 示している。(c) は原系の下フランジ板 $(990 \times 28)$ を本 橋の最大径間 P-5 P-6 径間の下フランジ板 (1 500× 50) に置換して立体骨組系の理論值を算出したものであ る。鋼床版の荷重分配に改善傾向が認められる。主桁下

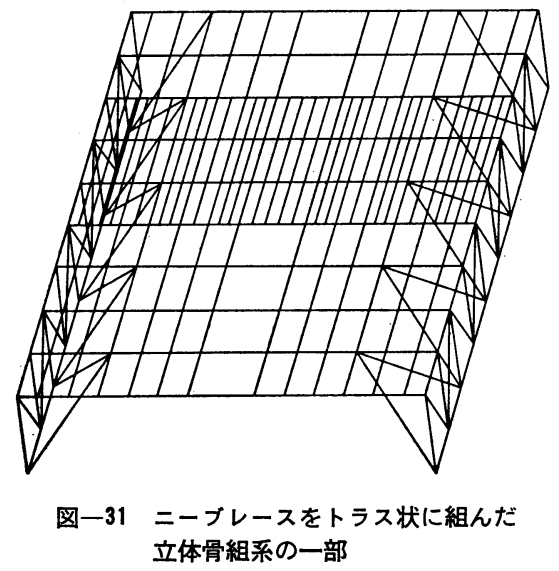

フランジの横方向曲げモーメントが大幅に増加している が，別途計算するとフランジの横方向断面係数の増大に より横曲げ応力は逆に $2 / 3$ に減少する。このことは二主 桁橋の下フランジはその総厚を厚くするよりむしろなる べく幅広に形作る方が，フランジの座屈安定のみならず 床組との相関関係においても有利であることを示してい る。最後の（d）の系は荷重分配が良いこと，フランジ の二次応力の抑制の面で顕著な利点を示している。問題 点として橋軸方向にも斜角を有する上にニーブレース上 端の銅床版に縦桁を要するなど構造の複雑化，箱桁に準 ずるせん断流の発生によるニーブレースの断面増大，お よび充腹構造の主桁とトラス構造のニーブレースとの間 のせん断力分担比率の解明を要するなどの諸点があげら れる。

最後に動的挙動測定については近く別途発表が予定さ れているので, 検討項目のみ記すと，走行トラックによ る橋体の振動測定および歩道上の人体に対する心理的影 響の検討, トラックの後輪落下による橋体の振動測定と 個有振動の検討，測定器を塔載した乗用車の走行による 車輛の振動測定および車輛内の人体に対する心理的影響 の検討などがその内容である。最後の車輛振動は路面平 坦度の検定を目的としたものであるが，近傍のボスポラ ス 海峡の吊橋上を本橋測定と同一条件で車輛を走行さ せ，比較データを採取・検討した。

\section{（5）設計荷重と実験荷重との対比}

床組に対する設計荷重に等価のものとして L-11，L$12, \mathrm{~L}-13$ 荷重にそれぞれ $0.616 ， 0.726 ， 0.950$ を乗じ た上これを重㸚わせた荷重を考えた。これらの3つ の荷重の横リブ反力合計が, 設計に用いた 3 軸荷重 （AASHO 荷重の $10 \%$ 増）による横リブ反力と等価に なることを利用したものである。次に L-11, L-12, L13 による測定応力にそれぞれ上記係数を乗じて設計活 荷重に対する実応力を換算し，許容応力に対して余裕の 
成瀬：

あることを確認した。縦リブに関しては数值的な直接確 認は困難であるが，横りブが正常な挙動を示しているこ と, 前項で述べたとおり設計時と同じ手法で求めた測定 点の計算值が実測值とほぼ対比しうること，などから問 題ないものと判定した。横リブのたわみはその支間に対 し, 衝撃を含む活荷重に対し $\delta / L=1 / 700$, 静的設計荷重 に対し $\delta / L=1 / 870$ で, 本橋の特記示様書の許容範囲内 であった。主析については測定值がいずれも理論值を下 まわっていることから,これも問題ないものと判定した。

\section{9. 結論}

本橋は無事故で全架設工程を終了し，その後 1 年間の 保証期間中 4 万台/日 の交通に供用されたが，全般にな んら異常を認めず, 最終検収を完了した。本稿に報告し た検討事項の結論を要約すると下記のとおりである。

(1) 大型の二主桁橋においても下フランジの適当な 横支持, 局部座屈に対するフランジ断面形状の設計上の 配虑などを前提として, 他の橋梁形式と同様にカンチレ バー架設を行いうることを, 解析・模型実験・実橋測定 の各面から確認した。

（2）隅板により閉断面に形成された圧縮フランジ は, ねじり剛性・曲げ剛性とも増大し, 座屈強度向上に 有効であることを確認した。

(3) 隅板つき閉断面フランジの溶接による残留応力 は特に大きいとはいえず, フランジの座屈安定に大きく 影響することは考えられない。

（4）フランジ継手の強度確保の観点から, 極端に菱 形の高力ボルト配置は避けるべきであること, 摩擦接合 部の万一の目違いに対して 2 枚重ねの添接板の使用が有 効であることを実験結果から確認し，これを設計に反映 した。

（5）鋼床版横リブ腹板のスカラップ周辺には大きな 集中応力発生の可能性があるので, スカラップ形状を疲 労強度・座屈強度の面から十分検討する必要がある。

（6）広幅員二主析橋の場合, 橋体温度と桁伸縮量の 測定結果からみて, デッキ面への日光直射が伸縮量に大 きな影響を与えるので, 架設中の状態を含め支承の設計 に注意を要する。

（7）カンチレバー架設中および完成後の橋体の応力
測定を行い, 主桁応力の測定值が理論值と大差ないこと を確認した。

（8）完成後の床組に対する載荷実験を行い, 支間 24 $\mathrm{m}$ の鋼床版の挙動が応力・変形とも正常であることを確 認した。また鋼床版がニーブレース・主桁を含む立体系 の一部として挙動していること, この応力伝達機構が鋼 床版の荷重分配を助けていること，このさい主桁下フラ ンジの横変位とそれに伴う 2 次応力について注意する必 要のあることなどを解析・測定両面から明らかにした。

総括的な結論として, 従来安全面について未解明の問 題を残していた二主桁橋形式に関する解析的・実験的研 究の結果, この形式は軽量であるにかかわらず, 機能的 に十分信頼のおける構造系であることを確認した。

\section{0. むすび}

おわりに本橋の計画施工にあたり東京大学 奥村名誉 教授, 完成橋梁の載荷実験ならびに本稿のまとめについ て早稲田大学 平嶋教授, 現地における応力測定の方法 について早稲田大学 堀井教授, 模型による座屈実験に ついて大阪大学 前田教授のご指導を, またその他設計・ 実験などについて多くの方々の助力・助言をえたことを 記し、ここに厚く謝意を表します。

\section{菘考文献}

1）成瀬: Golden Horn 橋の計画と設計の概要, 橋梁と基 礎, 7 巻 12 号, 1973.

2）松下・結城：二主桁橋の設計上の諸問題一下フランジ およびウエブの座屈安定について—, 土木学会第 27 回 学術構演会構演概要集, I - $255,1972$.

3）結城・松下.安藤：二主析橋の横倒れ座屈実験, 土木学 会第 27 回学術講演会講演概要集, I - 248, 1972.

4）成瀬：大形圾験体による高力ボルト摩擦継手の実験的研 究, 土木学会論文報告集, 第 224 号, 1974.

5）日本造船研究協会第 120 研究部会 : 大型船の横部材にお けるスロット周辺のクラック防止に関する研究叝告書, 日本造船研究協会研究資料 No. 136, 1971.

6）中原・星：Golden Horn 橋の架設における工事の機械 化, 土木技術, 第 28 巻第 12 号, 1973.

7）中原・上条：ゴールボンホーン橋の工事概要, 橋梁, 第 11 巻第 4 号, 1975.

8) Golden Horn 橋 (Turkey) の応力測定, 石川島播磨技 報, 第 15 巻 2 号, 1975 .

9) Design Manual for Orthotropic Steel Plate Deck Bridges, AISC, 1963.

(1975.2.19 - 受付) 